\title{
A New Paradigm in the Therapeutic Approach of Early Childhood Caries (ECC)
}

\author{
Andreea Igna, Emilia Ogodescu, Magda Luca and Alexandru Ogodescu* \\ Department of Paediatric Dentistry, School of Dentistry, Victor Babes University of Medicine and Pharmacy, Romania
}

*Corresponding author: Alexandru Ogodescu, Department of Paediatric Dentistry, School of Dentistry, Victor Babes University of

Medicine and Pharmacy, Romania

\begin{tabular}{|c|}
\hline ARTICLE INFO \\
\hline Received: 幽 December 30, 2019 \\
\hline Published: 蔧 January 17, 2020 \\
\hline $\begin{array}{l}\text { Citation: Andreea Igna, Emilia Ogodes- } \\
\text { cu, Magda Luca, Alexandru Ogodescu. A } \\
\text { New Paradigm in the Therapeutic Ap- } \\
\text { proach of Early Childhood Caries (ECC). Bi- } \\
\text { omed J Sci \& Tech Res 24(4)-2020. BJSTR. } \\
\text { MS.ID.004085. }\end{array}$ \\
\hline
\end{tabular}

ABSTRACT

Keywords: Oral Hygiene; Buccal Surface; Pre-Cavitary; Enamel; Cavitary Lesions

\section{Introduction}

Early Childhood Caries (ECC) is a form of dental caries with rapid progression, affecting primary teeth soon after eruption. The distinctive pattern of ECC, affecting the upper incisors' buccal surface first, points to the aetiology: feeding on baby bottles for a prolonged period of time, with poor or no oral hygiene, thus allowing the oral bacteria to trigger a metabolic chain that will result in acid formation, which ultimately leads to enamel demineralization and dental caries [1]. Early debut, rapid progression and delayed notice of the condition by the parents are aggravating factors that contribute to the decrease of life quality in these children [2]. The treatment means varies depending on the severity of the condition, from preventive measures to complex restorative procedures. Regardless of the type of treatment applied, parental guidance towards maintaining a good oral hygiene of the child and establishing healthy dietary habits is crucial for the success of the treatment. Inclusion of dental education in the national programmes dedicated to infant parenting could make a big difference. Furthermore, if the first dental visit took place as early as the firstyear of life [3], it would lead to an early detection of ECC and therefore to a more conservative treatment. Pre-cavitary lesions (white spots) can be treated both in office and at home using special remineralization agents $[4,5]$. For the cavitary lesions there are now available multiple treatment options, done in a conservative and atraumatic manner: caries removal by manual instrumentation (with or without the use of enzymatic gels) followed by restoration [6], or caries arrest by application of a silver diamine fluoride solution onto the affected tissue [7], followed or not by restoration. Although both procedures were especially designed for use in paediatric patients to meet their needs, the latter procedure is more suitable in cases of very young age and limited cooperation. In conclusion, raising awareness among parents regarding ECC and including dental education in parenting programmes may lead to early detection of the condition that will raise the rate of preventive and conservative treatments in disfavour of subjecting young children to lengthy and complex restorative treatments. 


\section{References}

1. Berkowitz RJ (2003) Causes, treatment and prevention of early childhood caries: a microbiologic perspective. Journal Canadian Dental Association 69(5): 304-307.

2. Leong PM, Gussy MG, Barrow SY, de Silva-Sanigorski A, Waters E (2013) A systematic review of risk factors during first year of life for early childhood caries. International Journal of Paediatric Dentistry 23(4): 235-250.

3. Fleming P (2015) Timetable for oral prevention in childhood-a current opinion. Progress in orthodontics 16(1): 27.

4. Cury JA, Tenuta LM (2009) Enamel remineralization: controlling the caries disease or treating early caries lesions?. Brazilian oral research 23: 23-30.

ISSN: 2574-1241

DOI: $10.26717 /$ BJSTR.2020.24.004085

Alexandru Ogodescu. Biomed J Sci \& Tech Res

(C) This work is licensed under Creative

Submission Link: https://biomedres.us/submit-manuscript.php
5. Vashisht R, Indira R, Ramachandran S, Kumar A, Srinivasan MR (2013) Role of casein phosphopeptide amorphous calcium phosphate in remineralization of white spot lesions and inhibition of Streptococcus mutans? Journal of conservative dentistry: JCD 16(4): 342.

6. Motta LJ, Martins MD, Porta KP, Bussadori SK (2009) Aesthetic restoration of deciduous anterior teeth after removal of carious tissue with Papacárie. Indian Journal of Dental Research 20(1): 117.

7. Fung HT, Wong MC, Lo EC, Chu CH (2013) Arresting early childhood caries with silver diamine fluoride-a literature review. Journal of Oral Hygiene and Health 1(3).

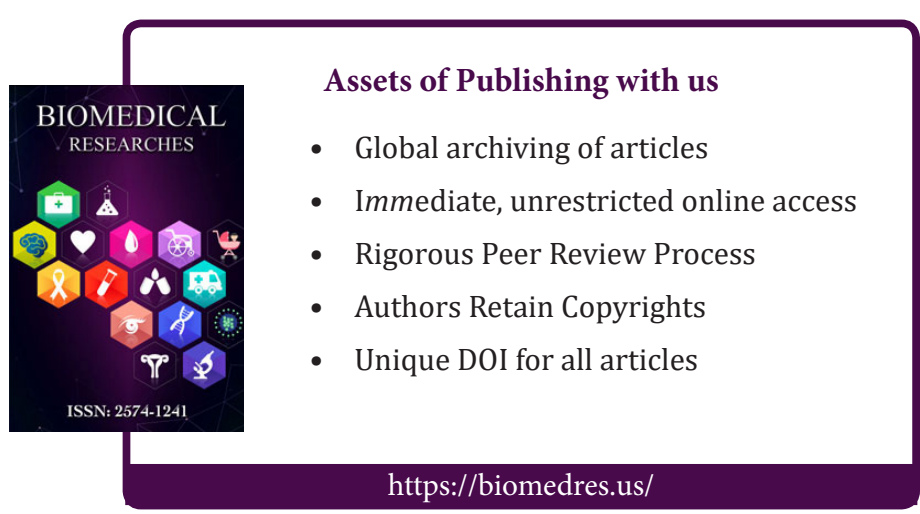

